\title{
PENATAAN BRANDING PELATIHAN DIGITAL MARKETING DAN PELATIHAN KEUANGAN SEDERHANA UNTUK UMKM DI KAMPUNG LAUK - KABUPATEN BANDUNG
}

\author{
Heppy Agustiana Vidyastuti \\ heppy.agustiana@ekuitas.ac.id \\ Henny Utarsih \\ henny.utarsih@ekuitas.ac.id \\ Erlynda Yuniarti Kasim \\ erlynda_kasim@yahoo.com
}

\section{SEKOLAH TINGGI ILMU EKONOMI EKUITAS}

\begin{abstract}
ABSTRAK
Usaha D'LA Fish, baby fish terletak di Kampung Ikan/Lauk di Kecamatan Ibun, khususnya Desa Lampegan. Dalam menjalankan usahanya, mereka menghadapi beberapa hambatan seperti terbatasnya kapasitas produksi karena mesin spinner yang rusak, terbatasnya pangsa pasar membuat penjualan stuck, dan permasalahan lain yaitu laporan keuangan yang kurang baik. Tim Pengabdian kepada Masyarakat ini mempunyai tujuan untuk mengatasi permasalahann ini dengan pemberian spinner, pelatihan penataan branding,digital marketing, dan pembukuan keuangan sederhana dan perhitungan harga pokok penjualan. Dengan diberikan spinner produk baby fish lebih tahan lama dikonsumsi karena tidak cepat tengik, dengan penataan branding dan digital marketing dapat mendukung perluasan pangsa pasar media media social seperti facebook \& instagram, sehingga penjualan meningkat. Setelah dilaksanakan program Pengabdian Masyarakat pada usaha tersebut, pemilik usaha Dla Fish, menyatakan bahwa proses produksi menjadi lebih cepat dan pelaksanaan administrasi lebih baik. Ke depan diharapkan dapat melihat peningkatan produktifitasnya secara keuangan.
\end{abstract}

Kata kunci: Baby Fish, Branding, Digital Marketing, Keuangan Sederhana.

\section{PENDAHULUAN}

UMKM D'LA Fish, baby fish dan pepes ikan terletak di Kampung Ikan/Lauk di Kecamatan Ibun, khususnya Desa Lampegan. Kecamatan Ibun memiliki luas wilayah 4.442 Hektar. Kampung Lauk salah satu ikon 1000 kampung yang dikembangkan di Desa Lampegan, Kecamatan Ibun, Kabupaten Bandung. Kampung lauk (kampung ikan) tersebut menjadi sumber ekonomi masyarakat setempat. Kampung lauk di desa tersebut sudah lama dikembangkan H. Ajin Suryana (alm), sehingga ia sempat mendapatkan penghargaan Kalpataru dari Presiden dalam bidang lingkungan Dengan banyaknya kolam ikan yang ada di kampung lauk tersebut sehngga masyarakat sebagian besar bermata pencaharian sebagai wiraswasta kolam ikan air tawar dan sebagai pedagang, 
hal tersebut menandakan bahwa masyarakat kampung Lauk memiliki dasar jiwa wirausaha dibandingkan dengan masyarakat lainnya di daerah tersebut.

Pemilik Usaha adalah ibu Aema dengan dibantu kelompok usaha berjumlah 10 orang memulai usahanya pada tahun 2018, berawal dari hadirnya penyuluh dari dinas kabupaten memberikan arahan dalam memproduksi berbagai macam olahan ikan, maka pemilik mempunyai keinginan untuk membantu menambah penghasilan keluarga. Pada saat itu dengan dibantu bu camat memotivasi untuk berkreasi dibidang olahan ikan sehingga dapat membantu penghasilan keluarga. Produk awal pertama dibuat bersama sama kelompok usaha dan dapat menghasilkan $25 \mathrm{~kg}$ ikan perbulan baik ikan baby atau ikan pepes, penjualannya pertama dilakukan pada bazar dan juga word of mouth sehingga dapat pesanan dari Bandung dan Riau tetapi belum rutin karena tidak menggunakan spinner jadi produk ikan terseut tidak awet/mudah tengik jika dikemas masih terdapat minyak hasil gorengan ikan.

Kondisi bauran pemasaran usaha D'La fish saat ini adalah sebagai berikut:

a. Produk memiliki beberapa kelebihan diantaranya, baby fish lebih kering dan tidak patah patah karena penggorengan yang sangat hati-hati. Ukuran D' La Fish disesuaikan dengan kebutuhan dan daya beli konsumen yang bervariasi. D' La Fish dikemas dalam berbagai ukuran, untuk baby fish 1 ons $-1 \mathrm{~kg}$, untuk pepes ikan mulai dari $1 / 4 \mathrm{~kg}$ sampai dengan $1 \mathrm{~kg}$

b. Harga D' La Fish ini cukup terjangkau, sehingga dapat dinikmati berbagai kalangan dimana harga baby fish 1 ons 35 ribu jika $1 \mathrm{~kg} 350$ ribu tergantung bahan baku nya, pepes ikan $1 / 4 \mathrm{~kg} 17.500$ jika $1 \mathrm{~kg} 70$ ribu-80 ribu.

c. Tempat Pemasaran D' La Fish ini di majalaya kecamatan Ibun, dan bisa juga berdasarkan pesanan d. Promosi yang dilakukan selama ini, yaitu menawarkan kepada setiap pedagang tentang produk ini, teman dekat dan lingkungan sekitar dengan kata lain promosi word of mouth. Peluang pasar untuk produk D' La Fish ini sangat besar melihat pertumbuhan kota Bandung dan peluang pasar yang menjanjikan dengan dekatnya jarak yang terkenal dengan salah satu pusat wisata kuliner.

Analisis terkait kondisi dan potensi wilayah dari segi fisik, ekonomi, dan sosial maupun lingkungan yang relevan dengan kegiatan yang akan dilakukan adalah sebagai berikut:

1. Segi Fisik

Usaha D'LA Fish berada di Kampung Ikan/Lauk terletak pada Kecamatan Ibun, khususnya Desa Lampegan. Akses menuju lokasi ini dapat dijangkau baik dengan kendaraan roda dua, maupun dengan kendaraan roda empat. Usaha ini merupakan usaha rumahan sehingga tempat produksi masih bergabung dengan rumah tinggal.

Sarana dan prasarana yang dimiliki oleh usaha D'La Fish antara lain sebagai berikut:
a. Mesin Spinner (rusak)
b. Timbangan kecil (5kg)
c. Penggorengan
d. Spatula
e. Tampah
f. Kompor gas
g. Panci besar

2. Segi Sosial

Masyarakat sekitar wilayah Kampung Ikan/Lauk berada di Kecamatan Ibun, khususnya Desa Lampegan pada umumnya relatif sudah mengenal usaha D'La Fish ini, sehingga tidak perlu lagi mencari atau bertanya untuk sampai di lokasi produksi atau usaha. Masyarakat sekitar dan luar misalnya untuk Bandung merasa kesulitan untuk membeli D'La Fish karena belum adanya pemasaran secara online dan sulitnya pembelian D' La Fish dengan Go-Jek. 


\section{Segi Ekonomi}

D'La Fish merupakan usaha rumahan, sehingga secara ekonomi sisi permodalan terutama ekonomi, masih tergantung pada dan bersumber dari pendapatan rumah tangga dan kelompok usaha, sehingga belum terpisahkan secara profesional.

Masalah utama yang dialami oleh usaha D' La Fish sebagai berikut:

1. Peralatan yang digunakan untuk produksi masih skala untuk penggunaan kegiatan memasak sehari- hari misalnya penggorengan kecil dan sebagainya sedangkan untuk pembuatan baby fish dibutuhkan mesin spinner sehingga kualitas produknya tidak banyak mengandung minyak.

2. Pemasaran masih berupa word of mouth dan pemasaran masih membutuhkan pemasaran branding, kurang memahami masalah dari digital marketing dan juga belum menerapkan analisis laporan keuangan yang sederhana. Saat ini mitra akan ditawarkan pembentukan pasar baru dengan memperkenalkan pada komunitas Masyarakat Marketing Indonesia, binaan P3M Ekuitas dan pembuatan akun di Facebook dan Instagram serta pendaftaran aplikasi go-food pada Go-jek. Dengan ini diharapkan omzet penjualan D'la fish dapat meningkat.

3. Perizinan halal, haki, BPOM belum dilakukan

4. Belum pahamnya terkait penyusunan laporan keuangan dan perhitungan harga pokok penjualan. Saat ini mitra belum menyusun laporan keuangannya dan belum paham dalam menghitung laba kotor.

Berdasarkan permasalahan yang dihadapi oleh mitra, beberapa alternatif solusi yang dapat ditawarkan adalah sebagai berikut :1. Pemberian mesin spinner untuk pengeringan baby fish sehingga tahan lama bisa sampai 2 bulan dan tidak mudah tengik.
2.Penataan branding dan Pelatihan $e$ marketing dimana dijelaskan bagaimana pemasaran yang efektif dengan promosi via media social, selain itu, mereka juga dipandu untuk membuat facebook \& instgram khusunya untuk berjualan. Promosi adalah salah satu aspek dari Marketing Mix yang berdampak signifikan dalam penjualan (Kottler \& Keller, 2016). Di era digital ini, Electronic Word of Mouth merupakan cara yang efektif dalam memperluas pasar bagi Usaha Kecil dan Menengah (UKM) (Spolter dkk, 2014). 3. Pembukuan sederhana.

\section{METODOLOGI PELAKSANAAN}

Rancangan mekanisme pelaksanaan kegiatan program ini dilakukan dengan mengadopsi langkah-langkah action research yang terdiri dari tiga tahapan, yaitu:

\section{a. Perencanaan}

Melakukan pertemuan dengan $\mathrm{Bu}$ Aema sebagai pemilik usaha, dan menjelaskan mengenai visi misi tim STIE Ekuitas dalam rangka Tri Dharma perguruan tinggi yang salah satunya adalah kegiatan pengabdian pada masyarakat. Tim juga menjelaskan akan adanya bantuan dari STIE Ekuitas pada UMKM binaan yaitu $\mathrm{Bu}$ Aema serta akan memberikan pemahaman penataan branding mengenai manfaat menggunakan fasilitas internet sebagai kegiatan untuk mempromosikan dan memasarkan produk, serta pelatihan pembuatan keuangan sederhana.

b. Pelaksanaan

Mengatasi masalah dari segi fisik seperti belum terpenuhinya alat produksi yaitu mesin Spinner. Mengatasi masalah dari segi sosial seperti masyarakat Bandung secara umum belum mengetahui keberadaan usaha D'La Fish. Membuat identitas dengan pembuatan Instagram, $\mathrm{Fb}$, WA dan e_commerce lainnya (Henny, 2017). 
Untuk mengatasi masalah pemasaran, khususnya peningkatan omzet penjualan, dikenalkan dengan komunitas Masyarakat Pemasaran Indoesia dan pemasaran secara online dengan pembuatan Facebook dan Instagram. Memberikan modul e-marketing penataan branding dan pembukuan keuangan sederhana (Heppy, 2017).

c. Tahap Akhir

Tahap akhir merupakan monitoring dan evaluasi. Tim pengabdian melakukan pendampingan sampai tercipta kemandirian pelaku usaha. Serta memantau hasil penjualan sebagai bentuk evaluasi dari pemberian bantuan yang telah dilaksanakan.

\section{HASIL DAN LUARAN}

\section{Hasil Kegiatan}

Target pengabdian kepada masyarakat adalah D"La Fish di Kecamatan Kampung Lauk Ibun Kabupaten Bandung adalah sebagai berikut:

1. Mengamati proses pembuatan D'La Fish

Hasil kegiatan pengabdian kepada masyarakat yang kami lakukan adalah mengamati proses pembuatan ikan D'la Fish. Di mana langkahlangkahnya sebagai berikut

1) Persiapan alat dan bahan yang digunakan dalam pembuatan D'La Fish, yang terdiri dari, pisau. alat tusuk, baskom/wadah ikan, seperangkat alat penggorengan, spinner, wadah penyajian, plastik bungkus, sealer.

2) Membersihkan organ ikan yang membuat rasa pahit (empedu) dibuang'. Pada tahapan ini penting untuk dilakukan karena dari sini akan menentukan kualitas dari ikan krispi D'La Fish, jika proses pembersihan ikan tidak dilakukan dengan benar maka ikan yang dihasilkan akan terasa pait dan tidak enak untuk dikonsumsi.

3) Pencucian sampai tidak berbau anyir ikan. Setelah bagian empedu ikan dibersihkan, maka proses selanjutnya dilakukan dengan mencuci ikan-ikan dengan air yang mengalir sehingga semua kotoran yang melekat ikut terbuang dan ikan sudah benar- benar bersih, kemudian disimpan pada wadah ang berisi es batu agar tetap segar.

4) Pembuatan bumbu ikan. Pada tahapan ini pembuatan bumbu D'La Fish, ikan dicuci dulu dengan menggunakan cuka sehingga menghilangkan bau anyir, setelah itu pembuatan bumbu ikan yang terdiri dari bawang merah, bawang putih, garam dan penyedap rasa.

5) Pencampuran ikan dengan bumbu yang sudah dihaluskan Pada tahapan ini, ikan yang sudah dibersihkan dan bumbu yang sdh duhaluskan dijadikan dalam satu wadah dan disimpan kurang lebih 30 menit sehingga bumbu tersebut sudah menyerap pada ikan.

6) Penggorengan ikan. Pada tahapan ini, ikan yang sudah diberi bumbu siap untuk digoreng. Penggorengan dilakukan dengan minyak yang berlimpah sehingga menutupi seluruh permukaan ikan, sehingga ikan yang didapatkan menjadi ikan krispi.

7) Ditiriskan. Pada tahapan ini, ikan yang sudah diberi bumbu siap untuk di goring. Penggorengan dilakukan dengan minyak yang berlimpah sehingga menutupi seluruh permukaan ikan, sehingga ikan yang didapatkan menjadi ikan krispi.

8) Dikeringkan dengan menggunakan spinner biar minyak yang ada pada ikan keluar. Pada tahapan ini, ikan yang sudah ditiriskan maka dilakukan pengeringan dengan 
menggunakan spinner sehingga benar-benar kering. Ikan-ikan yang kering ini akan dapat dikonsumsi dalam waktu yang lama karena tidak mudah bau apek.

9) Disajikan /dikemas. Pada tahapan ini, ikan-ikan yang sudah kering siap untuk dikemas dan dijual dengan memberikan tanggal proses produksi dan tanggal kadaluarsa.

2. Pembuatan Branding yang baik dengan memahami terlebih dahulu identitas brand anda, pertimbangkan karakter brand sejak awal, pilih mitra desain anda dengan hati hati, tetap jujur pada diri sendiri, sesuaikan brand dengan target pasar, membuat nama brand yang cukup unik agar mudah diingat, buat diferensiasi produk. Setelah menentukan nama dan logo brand yang baik tahap selanjutnya adalah membuat kemasan yang menarik serta membuat label untuk menambah identitas brand dan yang terakhir menyediakan garansi pada produk tersebut.

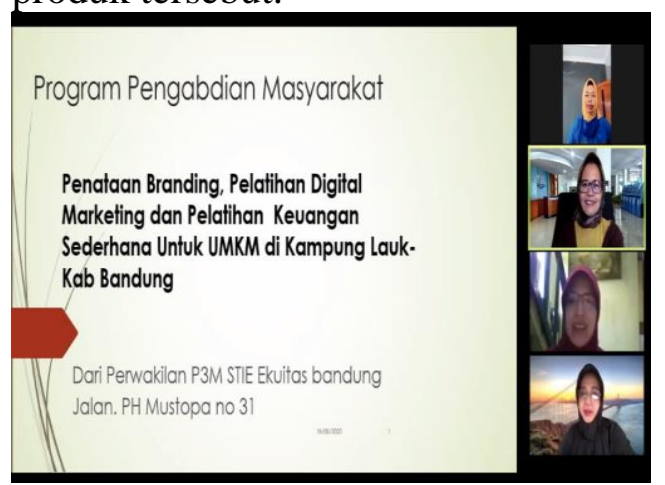

Gambar 1. Video Conference dengan Mitra Binaan.

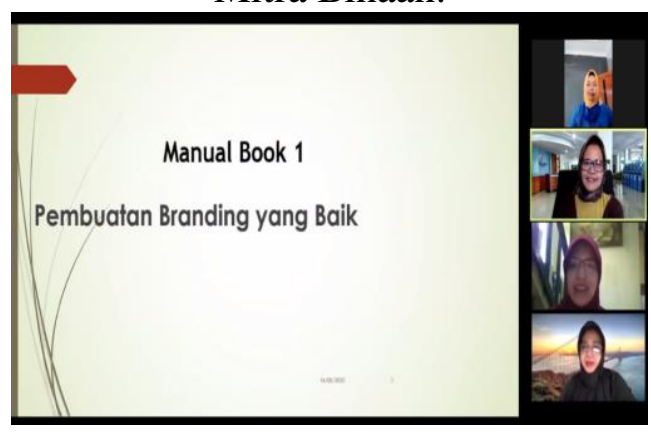

Gambar 2. Sosialisasi Pembuatan Branding yang Baik.
3. Sosialisasi Pemasaran Digital. Membantu pemasaran secara online dengan menjelaskan proses pembuatan e-marketing melalui pembuatan email, facebook dan Instagram. Tim STIE Ekuitas memberikan pelatihan e-marketing dengan cara menjelaskan tahap-tahap yang dilakukan dalam proses pembuatan email, facebook dan instagram. Pelatihan e-marketing ini juga dilakukan selama 30 menit dengan pendampingan. Kemudian $\mathrm{Bu}$ Aema diminta praktik langsung dalam proses pembuatan email, facebook dan instagram dengan menggunakan handphone yang dimiliki. Hal ini berguna untuk memasarkan produk yang nantinya akan dipasarkan lewat media sosial tersebut. Hal ini tentunya harus dilakukan secara bersamaan dengan motivasi UMKM untuk meningkatkan pasarnya melalui online sehingga terjadi peningkatan omset penjualan.

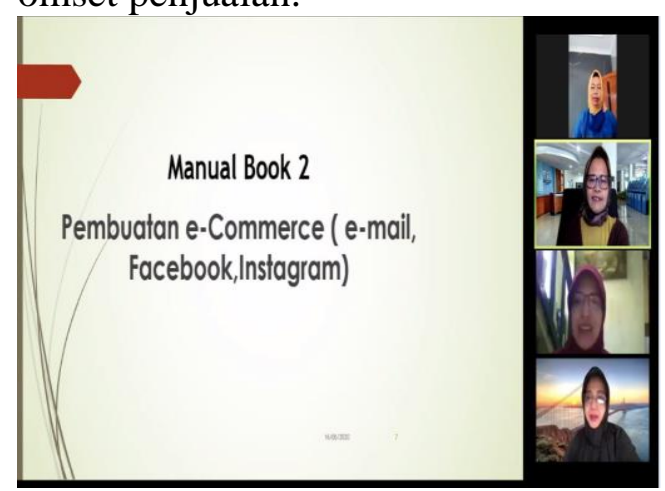

Gambar 3. Sosiaalisasi Pembuatan Digital Marketing.

4. Sosialisasi Pembukuan Sederhana. Pembukuan keuangan merupakan suatu hal yang sangat penting untuk anda lakukan, jika bisnis/usaha anda ingin cepat berkembang. Pembukuan adalah bagian dari sebuah alur akuntansi yang tidak dapat dilupakan. Tujuan dari pembuatan pembukuan yakni untuk mencatat seluruh transaksi yang terjadi dalam satu periode. Lebih lanjut, pembuatannya bisa dilakukan secara manual ataupun otomatis lantaran banyak software 
akuntansi yang menyediakannya. Adapun Tahapan yang dilakukan dalam melakukan pencatatan keuangan bisnis :

1) Pisahkan Rekening Pribadi dan Bisnis

2) Siapkan dokumen pendukung

Dalam transaksi kecil cukup hanya menggunakan bon / nota penjualan atau bahkan cukup di catat dalam buku penjualan harian. Misalkan menjual barang di warung/toko, cukup kita catat di buku penjualan harian saja. Karena kita juga tidak memberikan bon pada pembeli.

Jika menggunakan bon atau nota penjualan, harap menggunakan nomor urut. Hal ini untuk memudahkan pelacakan pencatatan di kemudian hari (tidak ada pencatatan double, menghindari / meminimalkan manipulasi jika transaksi dilayani oleh karyawan). Format Bon bisa menggunakan buku bon yang banyak di jual di toko-toko buku.

Sedangkan untuk transaksi yang besar terutama jika produk di jual ke konsumen perusahaan, maka mereka meminta invoice atau tagihan. Untuk transaksi bisnis ke perusahaan sebaiknya ditanyakan ke bagian pembelian atau keuangan-nya bagaimana tatacara kelengkapan dokumen untuk penagihan tersebut.

Pencatatan yang paling dasar adalah menggunakan Buku Kas. Dengan buku kas ini kita bisa mengetahui seberapa besar uang masuk, dan berapa besar uang yang keluar. Kita juga mengetahui saldo kas yang tersisa. Sehingga kita lebih hati hati dalam menggunakan uang untuk keperluan lain.

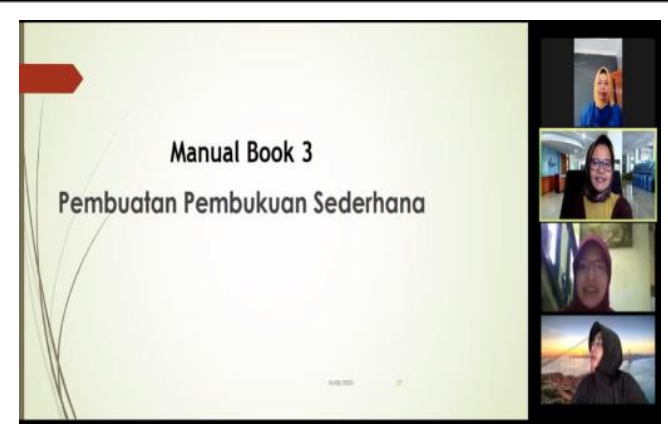

Gambar 4. Sosialisasi Pembuatan Pembukuan Sederhana.

5. Untuk mengatasi masalah produksi, kami memberikan mesin spinner, yaitu mesin pengering sehingga ikan yang dihasilkan tidak banyak mengandung minyak sehingga bisa lebh awet dan tidak berbau apek. Setelah diberikan spinner dapat bekerja maksimal bisa produksi lebih banyak karena produk lebih tahan lama dan awet di tangan para reseller hingga bisa tahan sampai 4 bulan.

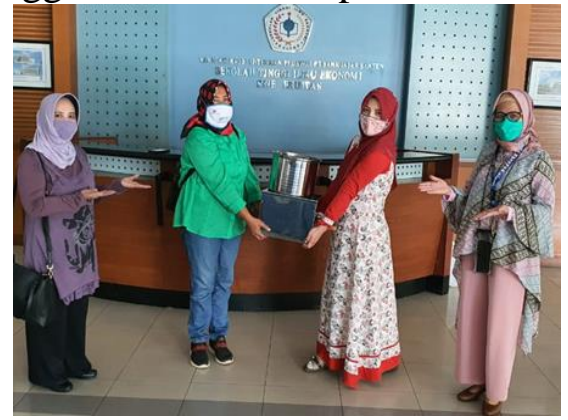

Gambar 5. Foto Penyerahan Alat.

\section{Luaran}

Jenis luaran yang akan dihasilkan dari kegiatan pengabdian masyarakat adalah;

1. Jasa, berupa bertambahnya keterampilan baru mengenai cara menggunakan Online Marketing untuk memperluas pangsa pasar D'la Fish. bertambahnya pengetahuan mengenai Branding serta pembukuan sederhana.

2. Produk, berupa pembelian alat produksi: Alat Spinner, yang digunakan untuk mengeringkan ikan yang sudah digoreng, sehingga makanan yang dihasilkan menjadi tahan lama.

Berikut hasil perbandingan antara sebelum dilakukan pendampingan kepada mitra binaan dan setelah dilakukan pendampingan 
Tabel. 1. Sebelum dan Sesudah PKM.

\begin{tabular}{|c|l|l|l|}
\hline No & $\begin{array}{l}\text { Perlakuan selama } \\
\text { Pendampingan }\end{array}$ & Sebelum PKM & Setelah PKM \\
\hline 1 & $\begin{array}{l}\text { Pelatihan pemberian } \\
\text { ilmu mengenai digital } \\
\text { marketing }\end{array}$ & $\begin{array}{l}\text { Masih konvensional } \\
\text { (offline) }\end{array}$ & $\begin{array}{l}\text { Sudah ditampilkan } \\
\text { di facebook }\end{array}$ \\
\hline 2 & Pelatihan Branding & $\begin{array}{l}\text { Yang diitampilkan di } \\
\text { kemasan belum } \\
\text { lengkap }\end{array}$ & $\begin{array}{l}\text { Sudah lengkap } \\
\text { terkait komposisi } \\
\text { atau tanggal } \\
\text { kadaluarsa }\end{array}$ \\
\hline 3 & $\begin{array}{l}\text { Pelatihan Keuangan } \\
\text { sederhana }\end{array}$ & $\begin{array}{l}\text { Masih campur dalam } \\
\text { penggunaan dana }\end{array}$ & $\begin{array}{l}\text { Sudah memahami } \\
\text { dan mulai } \\
\text { memisahkan dana } \\
\text { usaha dan dana } \\
\text { rumah }\end{array}$ \\
\hline 4 & Pemberian Spinner & $\begin{array}{l}\text { Produk yang dibuat } \\
\text { mudah tengik }\end{array}$ & $\begin{array}{l}\text { Lebih tahan lama } \\
\text { sampai 4 bulan }\end{array}$ \\
\hline
\end{tabular}

Sumber:Hasil Wawancara

Adanya bukti kemasan yang awalnya sederhana dari platik biasa setelah mendapatkan ilmu dari para dosen STIE Ekuitas menjadi tambahan pengetahuan dan akhirnya terjadi perubahan kemasan.

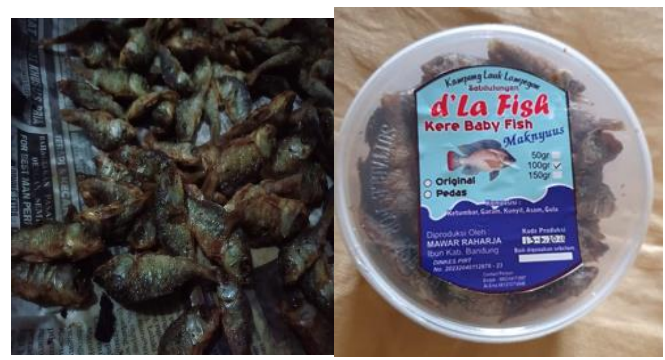

Gambar 6. Produk D’La Fish Sebelum dan setelah adanya PKM

Berdasarkan Tabel dan Gambar 6 dapat dijelaskan bahwa adanya kegiatan pengabdian kepada masyarakat pada usaha skala mikro Dla Fish memberikan dampak yang positf kepada mitra.

\section{KESIMPULAN DAN SARAN}

Untuk mengatasi masalah tidak tahan lamanya produk ikan D'La fish,tim pengabdian memberikan spinner sehingga ikan lebih tahan lama dan tidak cepat berbau tengi sehingga mitra semangat untuk memproduksi lebih banyak. Membantu perluasan pasar secara online dengan memberikan pelatihan membuat dan mengelola facebook \& intagram dan sosialisasi pembuatan branding yang baik. Untuk mengatasi masalah terkait keuangan dilakukan sosialisasi pembuatan pembukuan sederhana, sesuai dengan prinsip pembukuan sehingga dapat melihat hasil (kinerja keuangan) dari produksi D'La Fish.

\section{DAFTAR PUSTAKA}

Utarsih, H, Vidyastuti, H. A, Fitriani, E. (2017). Pembuatan berbagai jenis barang fungsional yang cantik, menarik,unik eksklusif dari bahan dasar sampah plastik dan pelathan emarketing.. Jurnal Dharma Bhakti Ekuitas, Volume 1 Nomor 2.

Vidyatsuti, H.A, Utarsih, H., Nurfitriana, A (2017). Pembuatan kerajinan "Decoupage, Pelatihan E-Marketing dan Pembauuatan Keuangan Sederhana di Kelurahan Cisaranten Endah kecamatan Arcamanik Jurnal Dharma Bhakti Ekuitas, Volume 2 Nomor 1.

Kotler, P and Keller, K.L. (2016). Marketing Management. 15 th Edition. New York. Prentice Hall. Pearson International edition.

Kotler, P and Armstrong, G. 2018. Priciple of Marketing. 17 th Edition. United States. Pearson International edition

Suryono, E. (2008), Cara Gampang Bikin Bisnis Franchise. Jakarta : PT Buku Kita.

Hantono dan Namira, R.U. (2018), Pengantar Akuntansi, Yogyakarta : CV Budi Utama.

Herdrik, K. (2010), Membuat Report Akuntansi Tanpa Repot dengan Excel (2007, Jakarta : PT Elex Media Komputindo.

Duwi, P. (2009), Akuntansi Sederhana untuk UKM dengan MS. Excel, Jakarta : PT Buku Kita.

Tri, W. (2015), Pantangan dalam Bisnis, Jakarta : PT Gramedia Pustaka Utama. 